\title{
The Book of Honor of the Iași Conservatory Returned Home!
}

\author{
CARMEN CHELARU \\ “George Enescu” National University of Arts Iași \\ ROMANIA*
}

\begin{abstract}
The Iași Conservatory Book of Honor was initiated in 1926, when the headmaster of the institution was the cello teacher Nicolae Theodorescu (between 1924-1930). I tried to describe the adventure of this document of great importance for the history of Iaşi culture, in the following episodes: personalities and events mentioned in the Book; the disappearance of the Book from the Conservatory archive in 1950, under circumstances still unclear; rediscovery and presence in D. Grumuzescu's collection; returning to the patrimony of the "George Enescu" Art University of Iasi. This text is an extension of the one published in "Filarmonica Magazine”, in April 2015.
\end{abstract}

Keywords: George Enescu, Iași, Conservatory, Book of Honor.

\section{Once Upon a Time in the Iași Old Town...}

Christmas 2018 was around the corner. One evening, I arrived at the antique shop of the Iași Old Town, Anticariatul Grumăzescu - everybody who visited Iași remembers this bookshop, full of vintage items, near Piața Unirii, Traian and Unirea Hotels, on Lăpuşneanu Street.

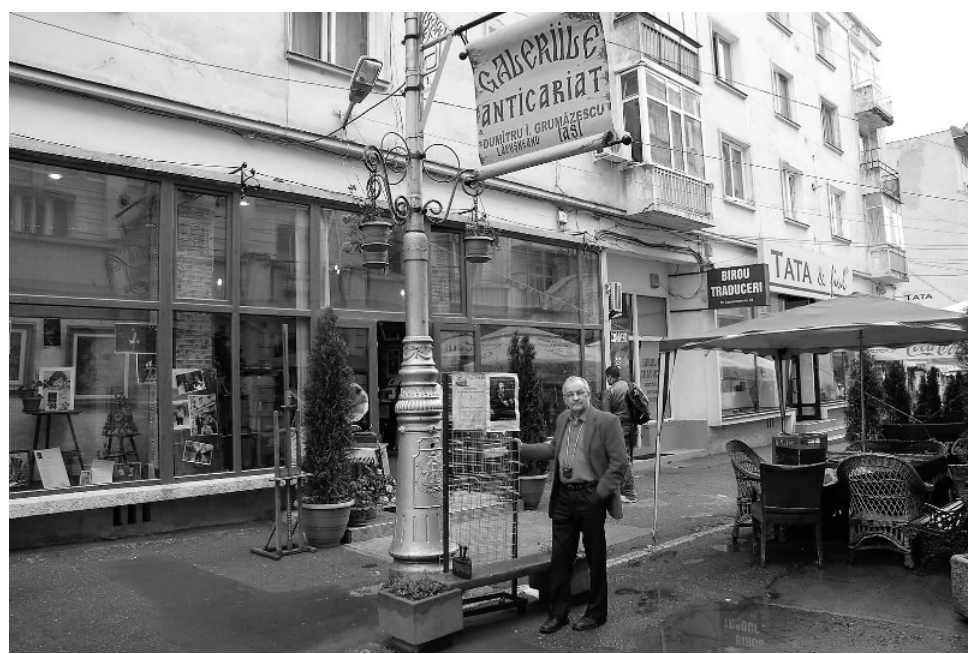

Fig. 1 Iași, The Antique Shop on Lăpuşneanu Street and its owner Dumitru Grumăzescu (Radio Iaşi/Photo ziaruldeiasi.ro)

* carmen.chelaru@gmail.com; sites.google.com/view/carmen-chelaru 
Four years ago, in January 2015, Dumitru Grumăzescu, the owner of the bookshop (he owns a very large collection of rare books), proudly told me about an item in his collection, The Honor Book of "George Enescu" Iași Conservatory of Music and Drama, 1926-1950. He talked, I browsed the yellow pages of the Book, I noticed George Enescu's autograph on a torn sheet and I left... At that time, I thought that if I write about this document in Filarmonica Magazine (Chelaru, 2015, pp. 30-37), something will happen, someone will take the initiative to bring it back to the University Library, where it has been taken from, a long time ago. But no, nothing did happen, life carried on untroubled. Only the owner was delighted to be promoted like this, and he ordered about forty copies of the magazine, to offer them to his friends and acquaintances.

\section{How I learned about the existence of the Conservatory Book of Honor}

In 2011, during a musicological meeting, Dumitru Grumăzescu talked about the historical document in his collection of rare books, mentioning the composer George Enescu's autograph. Everybody was astonished and I was very curious to see it. For various reasons, the opportunity arose only four years later, in January 2015. The collection owner invited the three of us to his bookshop (the Iași Philharmonic music secretary, a cameraman and me). He agreed to make an interview and to let us take photos of the document.

The main question was dealing, of course, with the circumstances in which he got the Book. So, he told us as following: "By 1976, I traveled to Bucharest on business, and, as usual, I visited the antiques fair, looking for rare books. After a while, I noticed an old man, with a wheelbarrow full of books. He agreed to let me look, and I found some precious genuine books. Finally, hearing that I came from Iași, he offered me a small book bound in leather: «Take this too, take it to Iași, the city of Iași owns it!» he said.
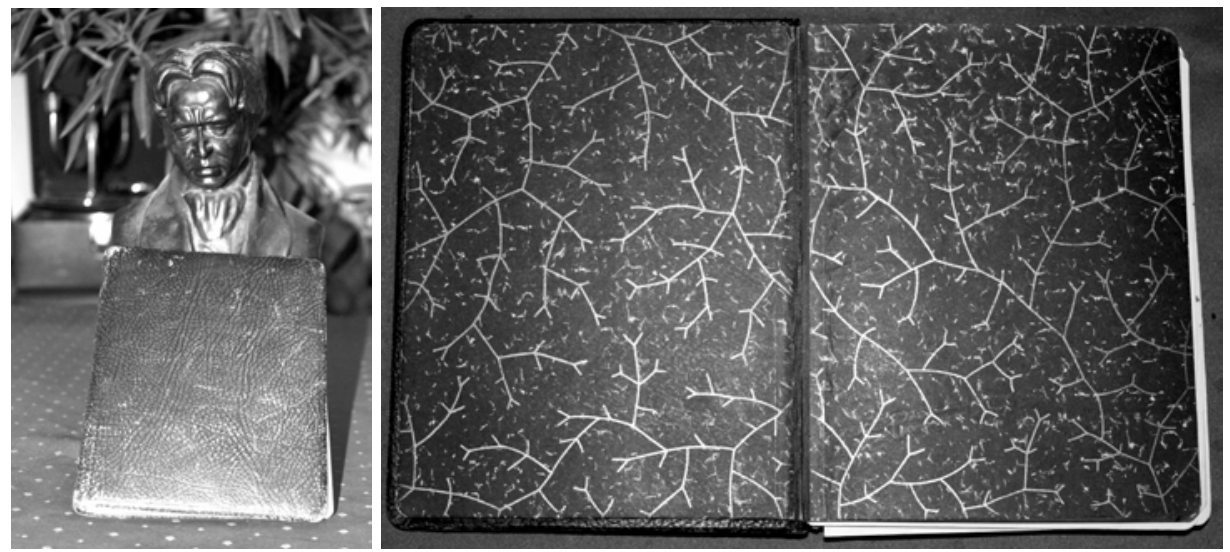

Fig. 2 (left) The Book of Honor and a small statue of the Romanian composer George Enescu, (right) Inside Cover (Photo: A. Popovici) 
And thus, this honor book containing signatures, dedications and references to the music history of Iaşi had come back home.”

\section{Shape and Content}

The Book size is 21/18 cm (8.267/7.086 Inches) and it includes about one hundred files; among them, only forty pages are written. The mentioning on the first page is not signed, so it could be written lately, by one of the owners (Fig. 3).

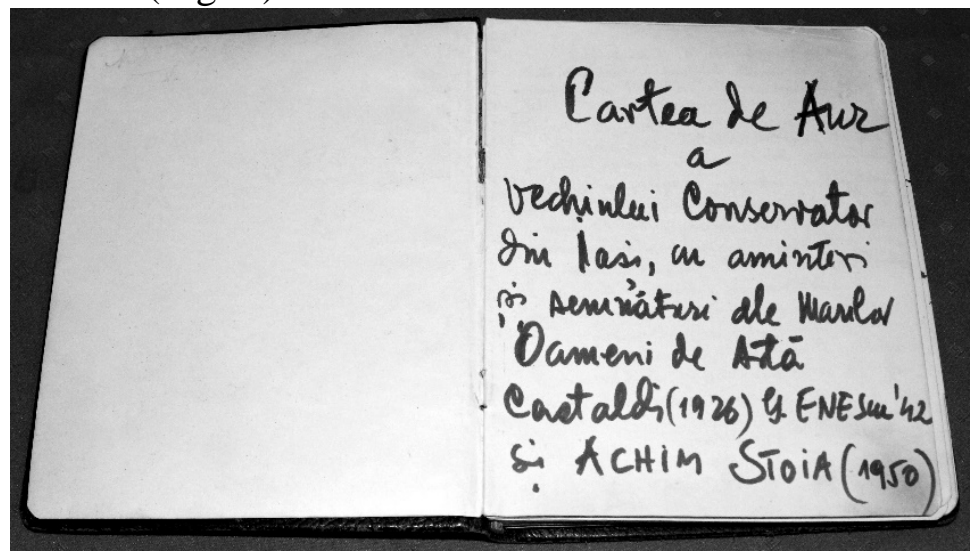

Fig. 3 The First Page: "The Book of Honor of the Iași Early Conservatory, with memories and signatures of great Artists as Castaldi (1926), G. Enescu (1942) and Achim Stoia (1950)" (Photo: A. Popovici)

Alfonso Castaldi, May 24th, 1926

The first mention, in Italian, belongs to the composer Alfonso Castaldi.

Sono contento ti poter affermare con turto is cuove is coustateto lalvore artistico musicale all'Orchertia Sel Couservatorio Jasi, Tizetto Jal valentissimo musicista Sigurer N. Teodoresen.

I resuetati artistici attemati in me in Tre Concerti Sinforici, Piretti recentemen te, mi convingono pppieno Sell efficacin

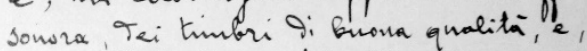
sematilto Jella perfetta Disciphina nelle varie e Sifficili esecenzioni tei the pro grammi. Ineata Orchestra, esetiranso. si metoticamente, ha certamente no bellissimo arvenire innanzi a de'; Son sicuro che fra nou mocto, esra notha- expondersi artisticamente, allangare le tue verute estetico-erolutive a raeco. ghere successi e triomifi.

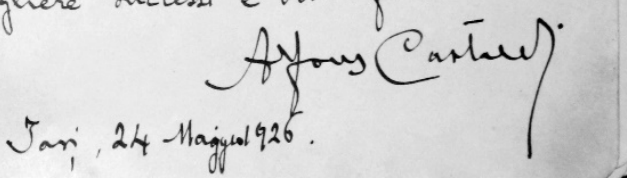

Fig. 4 Alfonso Castaldi's dedication to the musicians of the Conservatory (Photo: A. Popovici)

"I am happy to declare, with all my heart, that I have become aware of the artistic level of the Orchestra of the Iași Conservatory, whose head-master is the distinguished musician Mr. N. Teodorescu.

The artistic results we achieved in the two recent symphonic concerts convinced me by the efficient sound, by the beautiful color of the instruments, and above all, by the perfect discipline the two miscellaneous and difficult programs were performed. 
Working hard, this Orchestra has certainly a great future ahead. In a short time, I'm sure, it will grow artistically, expanding its stylistic horizons and winning triumphant successes."

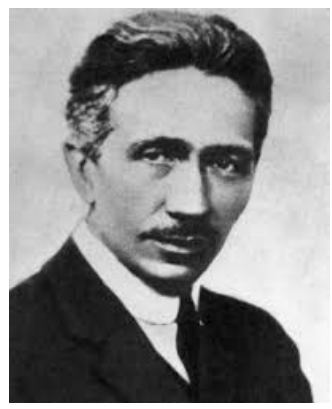

Fig. 5 Alfonso Castaldi

In 1926, Alfonso Castaldi (1874-1942, Italian composer, conductor and teacher, settled in Romania at the age of 20) was teaching harmony, polyphony, orchestration and composition at the Conservatory of Bucharest. He also was music inspector in The Arts and Culture Ministry (acc. to Tomescu, 1958). He conducted the Conservatory Orchestra in two concerts in March and May 1926, at the Iași National Theatre.

Fig. 6 The poster of the Concert of March 28th, conducted by Alfonso Castaldi: "The Orchestra of the Conservatory of Music and Drama, Iași/ The National Theatre/ Sunday, March 28th, 1926, 10:30 in the morning/ The Third Extraordinary Symphonic Concert, conducted by the Composer Maestro Castaldi” (Photo: GENUA ${ }^{2}$ Iași Archive)

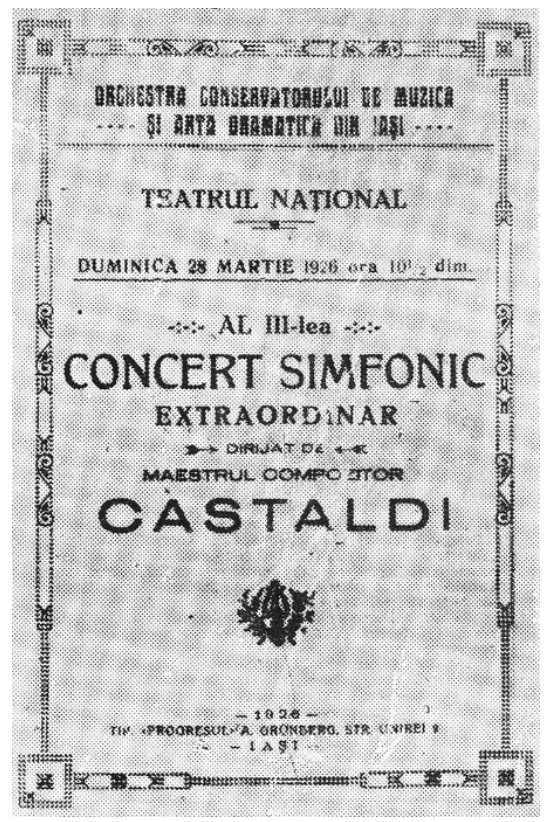

On May 25th, 1926, 'Opinia’ newspaper of Iași was publishing a large musical chronicle of those concerts, signed Wratislavius (pseudonym at Josef Shmilovich). I include an extract below.”... Mr. Castaldi immediately managed to relate with the auditors, the large crowd who filled completely the great concert hall. [...] I have

1 "Sono contento di poter affermare con tutto il cuore il constatato lavoro artistico-musicale all'Orchestra del Conservatorio di Iaşi, diretto dal valentissimo musicista Signor N. Teodorescu./ I risultati artistici ottenuti da me in due Concerti Sinfonici, diretti recentemente, mi convingono appieno dell'efficacia sonora, dei timbri di buona qualità, e, sopratutto della perfetta disciplina nelle varie e difficili esecuzioni dei due programmi. Questa Orchestra coltivando si metodicamente, ha certamente un bellissimo avvenire innanzi a sè;/ Son sicuro che fra non molto, essa potrà espandersi artisticamente, allargare le sue vedute esteticoevolutive e raccogliere successi e triomfi.” Translated by Carmen Chelaru (apud Pascu, 1964, p. 93, note 67)

${ }^{2}$ GENUA: "George Enescu” National University of Arts 
rarely noticed in a conductor such sincere modesty and so much honest faith in the performance of an artistic work."

According to the journalist, one of the concerts included extremely difficult scores such as Symphonie fantastique by Berlioz and Beethoven's Overture Leonore 3. "The conductor and the Conservatory Orchestra (composed mostly by students) have done their best. [...] I have not heard many times such passages so distinctly and harmoniously graded, as in Mr. Castaldi's performance.” (acc. to Tomescu, 1958, pp. 216-217)

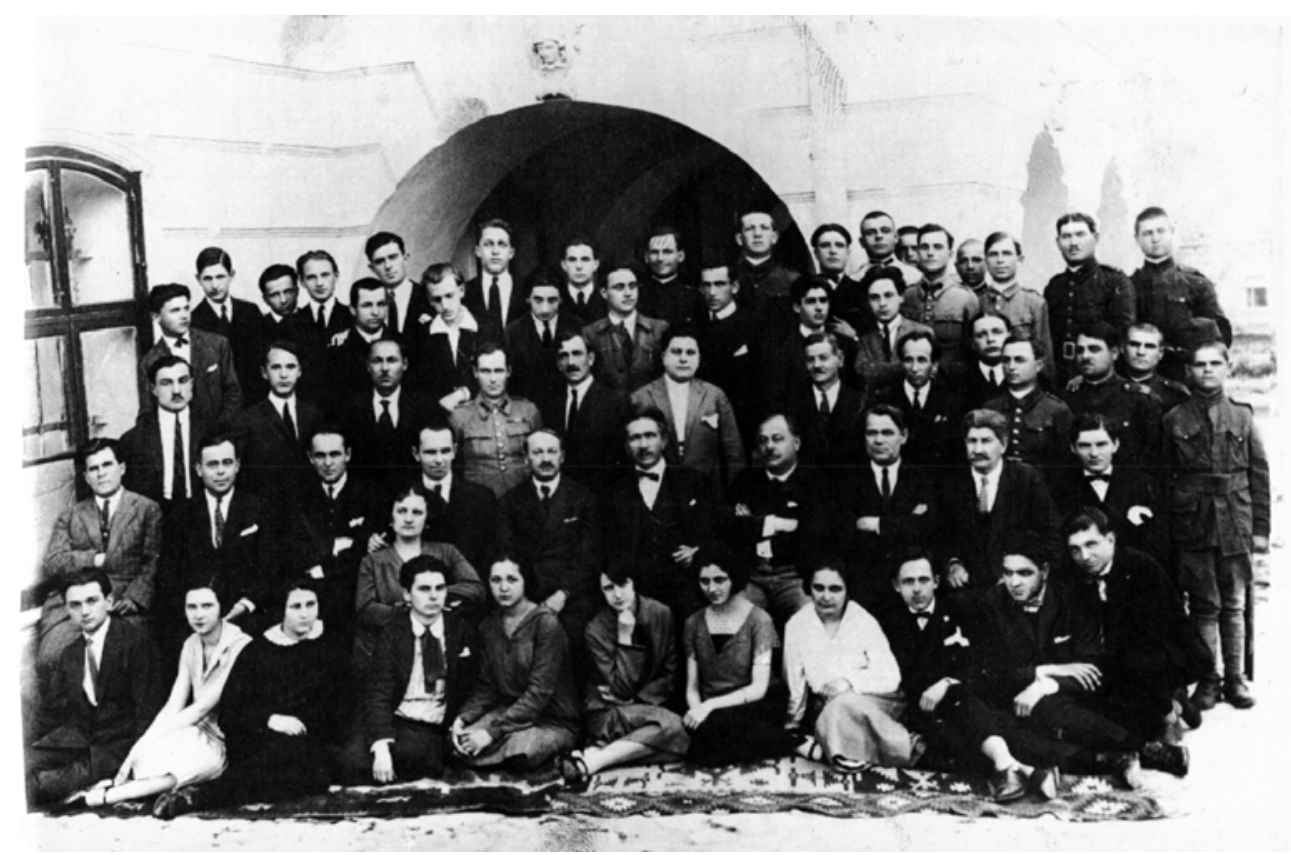

Fig. 7 Iași Conservatory Orchestra and the conductor Alfonso Castaldi (middle, 2nd line), in 1926 (Photo: GENUA Iași Archive)

On the Iași Philharmonic fifteenth anniversary, Professor George Pascu ${ }^{3}$ wrote: "Besides the concerts conducted by Carol Nosec, there are two other concerts with Professor Alfonso Castaldi from Bucharest. The excellent musician aroused enthusiasm among the auditors of Iași by the Beethoven's Eroica Symphony and Berlioz's Symphonie fantastique. He also impressed by his own works - original compositions and remaking from Baroque music" (Pascu, 1957, pp. 43-44). Seven years later Professor George Pascu was mentioning: "In the season 1925-1926, the orchestra performed four concerts, two of them conducted by Alfonso Castaldi. The Professor of Bucharest made a

3 George Pascu (1912-1996): Professor of the history of music at Iași Conservatory, musicologist, director and music secretary of the Iași Philharmonic, performer of musical conferences (Cozmei, 2010, Existențe..., pp. 327-332). 
profound impression as a conductor. By his Mediterranean temper he enhanced the orchestra, getting from the young ensemble genuine artistic performances. His compositions Tarantella and Marsyas, difficult works technically and artistically, have been very well figured out. As a result of the general enthusiasm, Tarantella has been repeated as an encore. Berlioz's music, almost unknown in Iași, produced a deep impression. The Symphonie fantastique performance became a musical event which a long time ahead will be talking about, among the music lovers of Iași. In the Conservatory Book of Honor, Castaldi himself mentioned the orchestra improvement.” (Pascu, 1964, p. 93)

Nicolae Theodorescu, Cellist and Professor, Headmaster of the Conservatory between 1924-1930

At that time, the cello teacher Nicolae Theodorescu (1885-1939) was the Iași Conservatory headmaster.

"After a period of very frequent changes (six headmasters in seven years), Nicolae Theodorescu took the Conservatory leading in 1924, and he imposed more discipline in the educational dealings, more stability in the teachers' activity. Above all, he hired new teachers in order to continue and to enrich the experience of the school as a high-level institution of artistic education." (Cozmei, 2010, Pagini..., pp. 137-139)
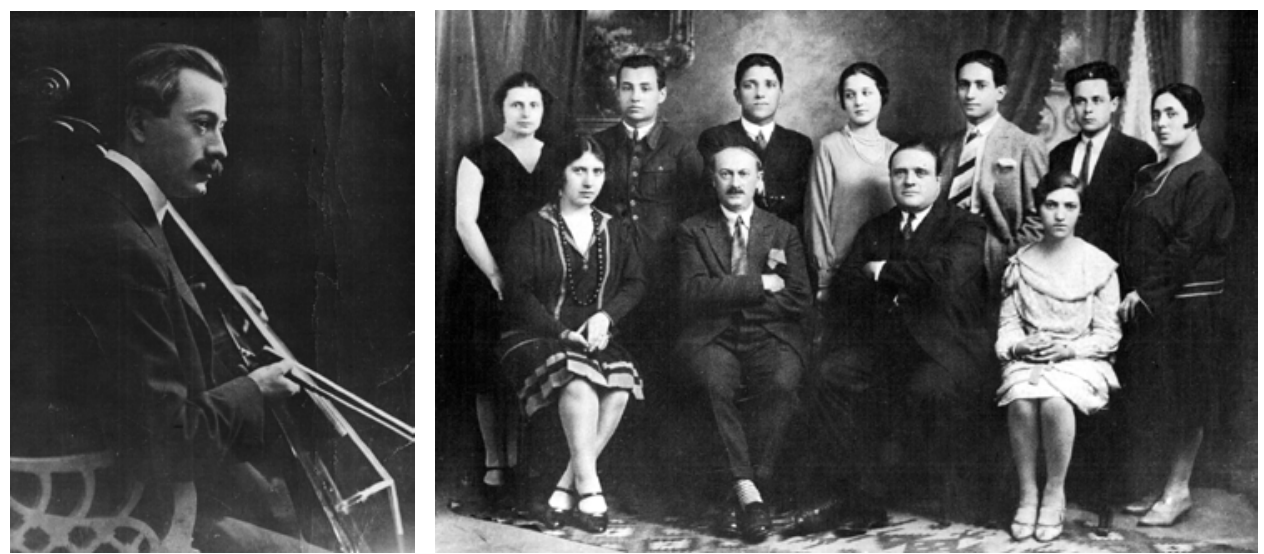

Fig. 8 (left) Nicolae Theodorescu,

cellist and headmaster of the Conservatory between 1924-1930;

(right) The students of Professor Nicolae Theodorescu, in 1928 (middle)

(Photo: GENUA Iași Archive)

In the next pages, the Book of Honor includes notes regarding the courses opening in the period 1940-1943, with the signatures of the teachers and further 
guests such as the Minister of National Culture, Religion and Arts, Professor Ion Petrovici ${ }^{4}$; also, poets and actors, important cultural personalities of the time.

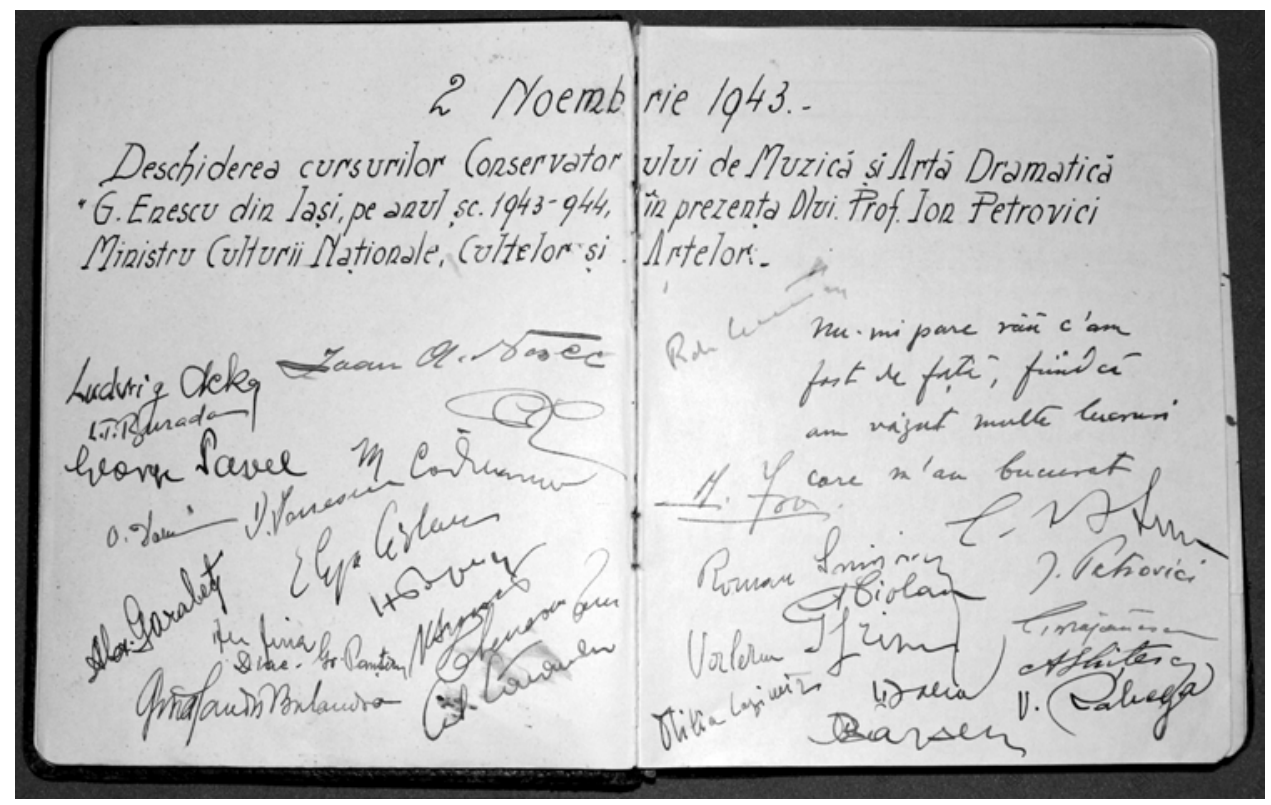

Fig. 9 Opening courses on November 2nd, 1943 (Photo: A. Popovici)

\section{Radu Constantinescu, 1945 (?)}

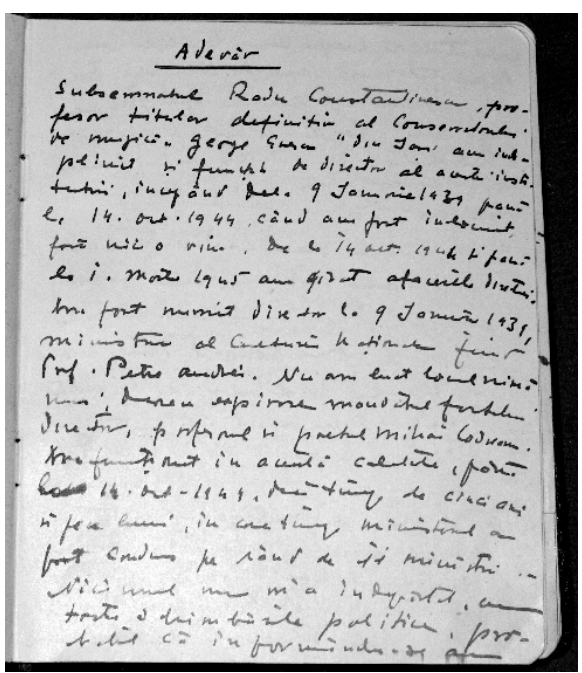

Fig. 11 The first page of the story written by Professor Radu Constantinescu (Photo: A. Popovici)
Fig 10.

Professor Radu Constantinescu (Foto: GENUA Iași Archive)

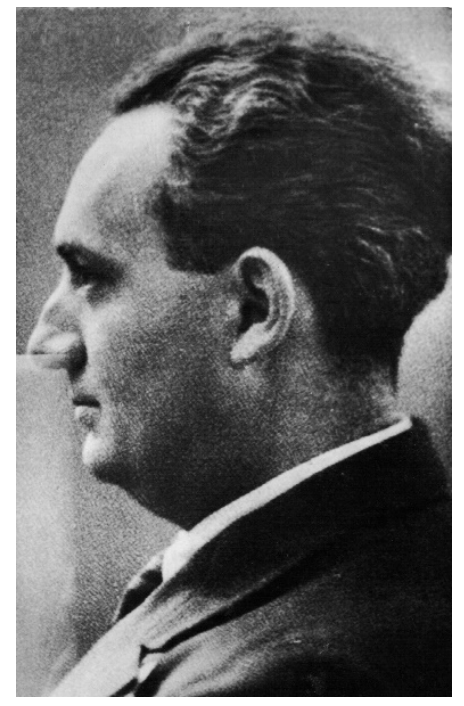

${ }^{4}$ Ion Petrovici, 1882-1972, Romanian Professor of philosophy at the University of Iaşi, Member of the Romanian Academy and Minister of National Education between 1937-1938 and 19411944. In 1943 he signed the Founding Decree of the Iași Philharmonic Orchestra. 
The Book includes also a rather long story (13 pages) of Professor Radu Constantinescu, intitled Truth, regarding certain events in the Conservatory educational sphere as well as in the city of Iași musical life.

Radu Constantinescu (1900-1986), has been pianist and Professor at the Iași Conservatory between 1925-1950. At the closing of the institution, in 1950, he left Iași for Bucharest, where he taught at the Music High School and at the Conservatory. He was soloist and a passionate chamber music performer. Between 1939-1950, he was also rector of the "George Enescu" Conservatory and promoter of the musical life in Iași. In 1940-1942 he decisively played a part in the foundation of the Iași Philharmonic Orchestra; he also leaded the concert institution till 1945 (Cozmei, 2010, Existențe..., pp. 123-124).

George Enescu, dedication and autograph, 1942 Enescu.

The most important autograph of the Book is that of the composer George

In 1942, George Enescu came to Iași to participate at several musical events. On May 15th and 17th, he performed recitals as a violinist, and on October 9th, he conducted the inauguration concert at the Iași Philharmonic. I did not find precise information regarding the events of May 1942 (location, program of the concerts, etc.). Professor Mihail Cozmei ${ }^{5}$, who studied thoroughly the archives of the Iași Conservatory, mentioned that the record of the Professors Board includes information concerning the rector's mission, Professor Radu Constantinescu, to yield to maestro George Enescu the title of doctor honoris causa.

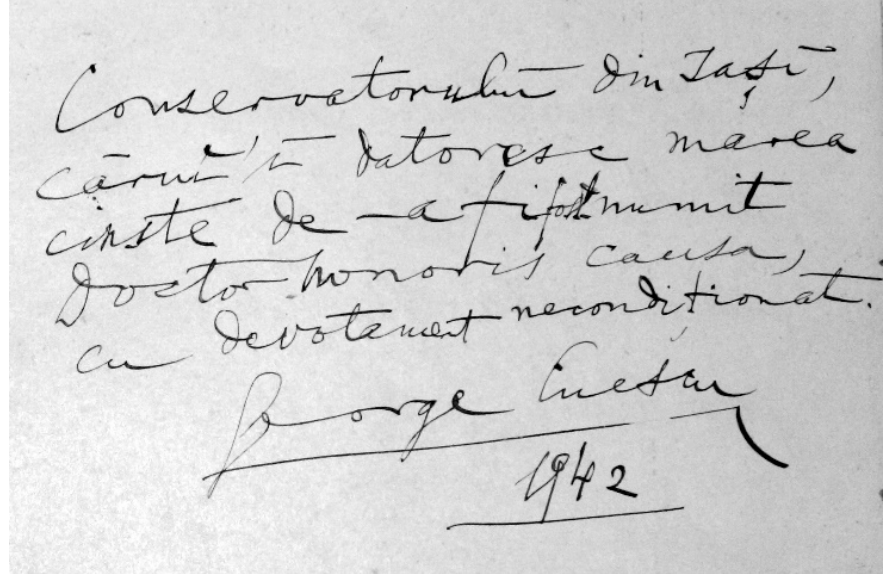

Fig. 12 "To the Iași Conservatory, to whom I owe the great honor of having been named doctor honoris causa, with unconditional devotion. George Enescu, 1942"

(Photo: A. Popovici)

${ }^{5}$ Mihail Cozmei, born in 1931, is music historian, former Professor at the Iași University of Arts, as well as the first music secretary of the Philharmonic (1956-1962). 
It seems that Professor R. Constantinescu did meet Enescu in Bucharest, in order to fulfill this mission. At the same time or probably sometime later, the famous composer did write the words of acknowledgment in the Book of Honor (Fig. 12).

At present, we do not know under what circumstances the page with Enescu's acknowledgement and signature has been detached and torn from the Book, who did this, what for, who kept it and above all, who gave it to D. Grumăzescu in 2010 - the art collector refused to unveil the name of the donor.

It is beyond any doubt that the page has been broken from the document in question; the mentioning on next two pages is relevant (see Fig. 13).

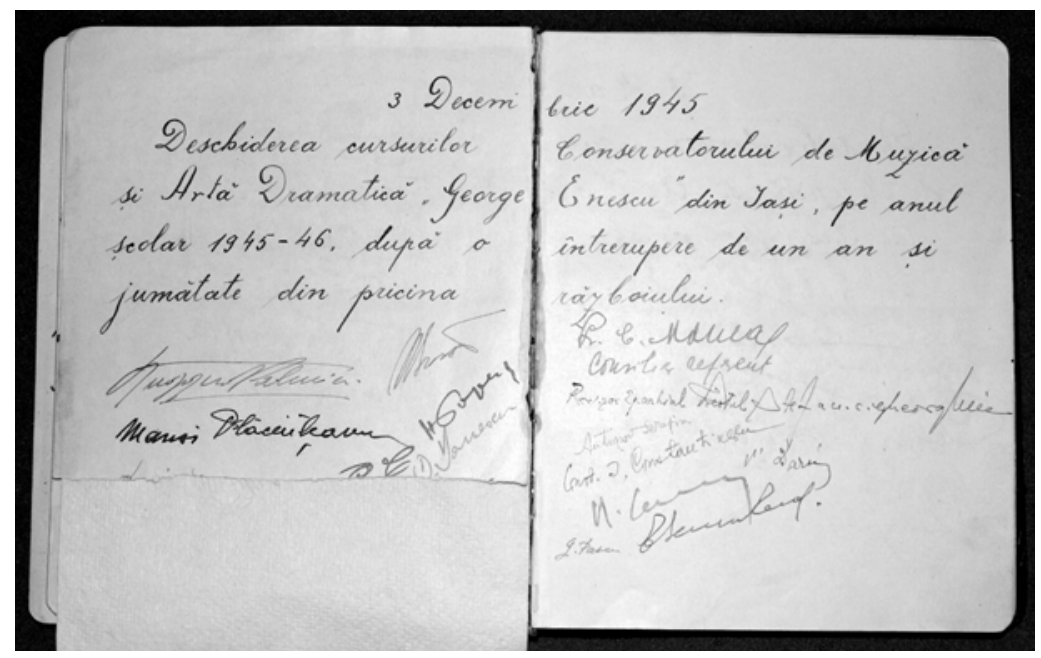

Fig. 13 The back page of George Enescu's autograph includes a text which goes on the next page.

(Photo: A. Popovici)
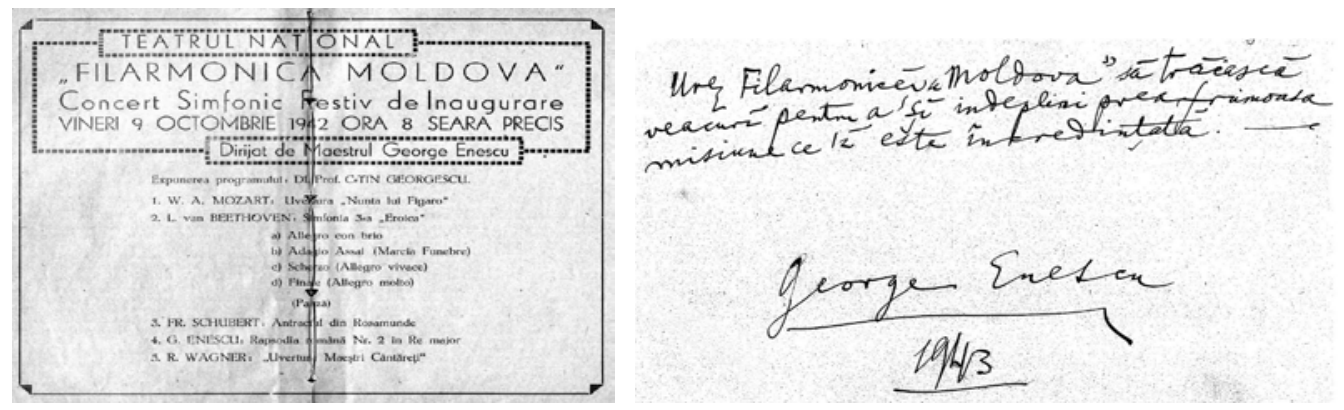

Fig. 14 (left) The poster of the October 9th, 1942 Concert;

(right) George Enescu's dedication and autograph in The Iași Philharmonic Book of Honor: "I wish the 'Moldova' Philharmonic to live for centuries in order to carry out its entrusted precious mission. George Enescu, 1943” (Photo: Iași Philharmonic Archive) 
It's almost incredible how fate has brought together The Book and its broken page - two important documents for the musical history of Iași!

The Philharmonic Orchestra inauguration, which took place by the same period, did leave explicit documents in the archive of the Iassi Philharmonic: the concert poster, the program and, a year later, the famous dedication signed by Enescu in the Philharmonic Book of Honor (Fig. 14).

\section{The Last and Sad Note, November 1st, 1950}

The other pages include notes about certain events in the period 1944-1949, related to the educational activity of the Iasi Conservatory.

The last text, signed by Achim Stoia ${ }^{6}$, Professor, composer and rector of the Conservatory, mentions a tragic event: "November 1st, 1950. The closing down of the Iași Art Institute. After a brilliant activity for a century, the academic art school closes its gates today. A mourning day for the culture of Iași, of Moldova. Achim Stoia, Rector of the Iași Art Institute” (Fig. 15).

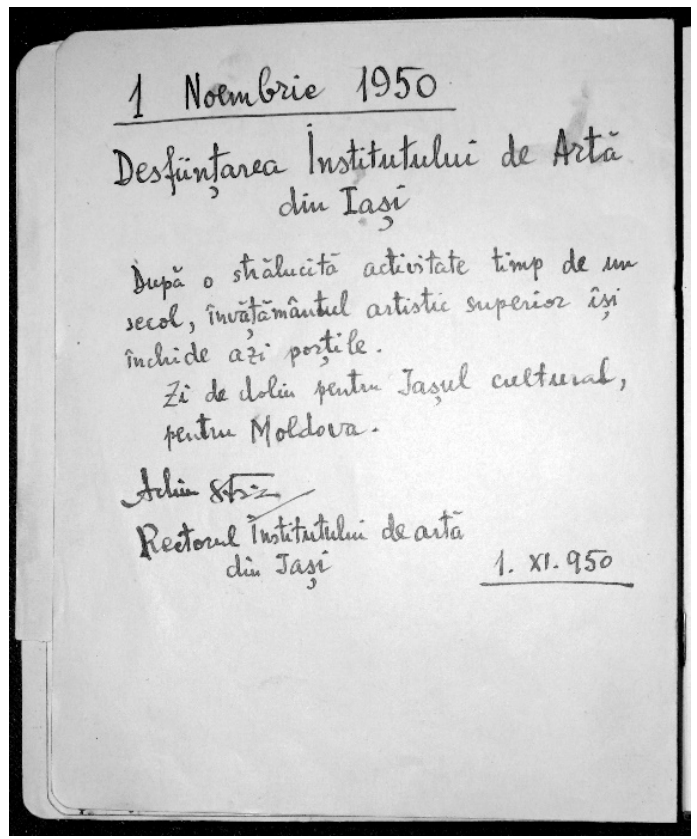

Fig. 15 The last note in the Iași Conservatory Book of Honor (Photo: A. Popovici)

One can imagine the despair of the Iasi musicians following this event, which interrupted a century-long activity. The history has not once proven that it is much easier to destroy than to build or maintain continuity. In 1960 (after ten years!) the Conservatory reopened, but by the end of their lives, the teachers who have experienced the tragic event have kept alive the memory of that moment!

Some of the teachers were hired at the Music School (founded on November 1st, 1949) - today "Octav Băncilă” National Art College. The others - Professor Radu Constantinescu among them - left Iași and moved to Bucharest.

${ }^{6}$ Achim Stoia (1910-1973), was born in Transylvania and he studied music in Bucharest and Paris. In 1943, he settled in Iași for good. He has been Professor and rector of the Conservatory, conductor and director of the Iași Philharmonic Orchestra, successful Romanian composer. 


\section{... And a Happy-End, December 20th, 2018!}

That was the true story of the Iași Conservatory Book of Honor exceedingly important document for the history of music and the artistic education in Iași. Of course, its presence in a private collection could be a guarantee of keeping it under optimal conditions. But why wouldn't it return to the patrimony of the institution that produced it? - in 2015 I ended my article by this rhetorical question.

In June 2018, Dumitru Grumăzescu passed away. Then, naturally, I thought again what would happen to the Conservatory Book of Honor. I asked a few questions, I waited for reactions... and the time passed again, till mid-December. One night I was standing once more by the bookshop of Lăpușneanu Street. On the door, a notice about the sale of books and objects inside at the cheapest price worried me. This time I realized I must not wait longer, and I came out of inertia.

Ladies Elena Știrban and Ionuţa-Veronica Iwanaga - the owner's wife and daughter, who are the inheritors of the bookshop - with great generosity, agreed to donate the Book of Honor towards the institution of which it has belonged from the beginning.

Well, in less than 48 hours from the first contact with the collector's family, on December 20th (2018), the precious Book took its place back in the Library of the "George Enescu" National University of Arts!

We express here again our gratitude to the ladies Ionuța-Veronica Iwanaga and Elena Ştirban for their altruist and noble gesture!

The Book will be attainable to the readers in electronic form. For protection reasons, according to the laws regarding the preservation of the historical documents, the original will have limited circulation.

January 15th, 2019

\section{References}

*** (1926-1950). Cartea de Aur a Conservatorului din Iași [The Iași Conservatory Book of Honor].

Chelaru, C. (2015). Aventura unui document istoric [The Adventure of a Historical Document]. In Filarmonica Magazine No. 11, Iași, pp. 30-37.

Cozmei, M. (2010). Existențe și împliniri. Dicționar biobibliografic [Lives and Fulfillments. Biobibliographical Dictionary]. Iași: Editura Artes.

Cozmei, M. (2010). Pagini din istoria învățământului artistic modern din Iași, la 150 de ani [Moments from the History of the Artistic Modern Education in Iași, after 150 Years]. Iași: Editura Artes. 
Maftei, I. (2008). 1000 Personalități ieșene. Lexicon [One Thousand Personalities of Iași]. Iași: Editura Princeps.

(Pascu, G.) (1957). Filarmonica de Stat „,Moldova” Iași. 1942-1957, Cincisprezece ani de activitate. Program festiv ['Moldova' State Philharmonic Iasi, Fifteen years of activity. Festive program]. Iași. Întreprinderea poligrafică

Pascu, G. (1964). 100 de ani de la înființarea Conservatorului de muzică „George Enescu" din Iași, 1864-1964 [One Hundred Years since The "George Enescu” Iași Conservatory of Music has been founded, 1864-1964]. Iași: Întreprinderea Poligrafică.

Tomescu, V. (1958). Alfonso Castaldi. București: Editura Muzicală.

*** (1994). Anuarul Liceului de Arte Octav Băncilă Iași, la 45 de ani de existență 1949-1994 [The Forty fifth Anniversary of The Octav Băncilă Iași High School of Arts. Year-Book]. Ministerul Învățământului. Iași: Imprimeria Institutului European pentru Cooperare Cultural-Științifică Iași

*** Documents and Photos from the Iași Philharmonic Archive

*** Documents and Photos from the Library Archive of the "George Enescu" Iași University of Arts 